\title{
POR UMA ÉTICA NAS PRODUÇÕES AUDIOVISUAIS NA CIBERCULTURA: A INFÂNCIA EM VÍDEOS VIRAIS
}

\author{
FOR AN ETHICS IN AUDIOVISUAL PRODUCTIONS \\ IN CYBERCULTURE: CHILDHOOD \\ IN VIRAL VIDEOS
}

Perseu Silva ${ }^{1, *}$

Rita Marisa Ribes Pereira² (D)

\begin{abstract}
RESUMO: Este texto busca problematizar as imagens de crianças que circulam em vídeos on-line, propagando-se numa escala vertiginosa conceituada como viral. Que imagens de infância circulam? O que faz da criança uma imagem que viraliza? Que alteridade pauta a relação entre a criança que é filmada e aqueles que a filmam? Que ética baliza a produção e a circulação desses vídeos? Para enfrentar tais questões, trazemos uma discussão sobre vídeos virais que circulam nas redes e, mais amiúde, a análise crítica de dois vídeos para, a partir deles, buscar elementos para a construção de um agir responsável.
\end{abstract}

Palavras-chave: Infância. Cibercultura. Vídeos virais. Ética. Pesquisa com crianças

ABSTRACT: The purpose of this text is to question images of children that circulate in online videos, which are spreading on the dizzying scale conceptualized as viral. What childhood images circulate online? What makes the child become a viral image? What alterity guides the relationship between the children who are filmed and those filming them? What ethics marks the production and circulation of such videos? To address these issues, we bring a discussion about viral videos that circulate in networks, and critically analyze two of such videos, seeking elements for the construction of a responsible action.

Keywords: Childhood. Cyberculture. Viral videos. Ethics. Research with children.

1.Colégio Pedro II - Rio de Janeiro (RJ), Brasil.

2.Universidade do Estado do Rio de Janeiro - Rio de Janeiro (RJ), Brasil.

*Autor correspondente: perseusilva@gmail.com

Número temático organizado por: Gilka Girardello, Adriana Hoffmann e Inês Vitorino Sampaio 


\section{Vírus 1: "Quando o Papai Chega do Trabalho...."1}

O pensamento é nuvem

O movimento é drone

(Pela Internet ${ }^{2}$, de Gilberto Gil)

O grito de felicidade de Tim é a primeira coisa que se ouve. Quase simultaneamente, é possível ouvir a voz de sua mãe. Tim movimenta os braços, olha para trás e encontra a mãe filmando. Ela aparece apenas em voz. O menino se volta para olhar através do vidro da porta em que está apoiado. O pai acena de fora. Tim demonstra sua felicidade balbuciando palavras e gesticulando com os braços. A mãe diz: "Ai, que lindo, amor! Papai vai entrar, filho, vem aqui. Vamos lá pegar o papai na porta.” A criança continua apoiada na porta de vidro. “Tá feliz? Tá feliz, filho?”, pergunta a mãe, que, em seguida, dirige-se ao possível espectador do vídeo, explicando o momento.

O pai entra na casa e começa a falar. A mãe participa do diálogo dizendo que o menino está procurando pelo pai. Tim percebe que o pai entrou e vai engatinhando em sua direção. Em seu caminho, há equipamentos que a mãe sinaliza pertencerem a ela, pedindo ajuda ao pai para que o bebê não derrube os objetos. "Pega ele aqui, amor, vai derrubar tudo. Socorro", diz a mãe. Fala rindo e sem parar de filmar. E continua para o filho: "Não, amor, aqui não pode, meu tripé."

O pai, então, aparece e pega o menino nos braços, retirando-o do meio dos equipamentos. Pouco depois, o vídeo se encerra.

\section{Vírus 2: "Menino Chora Muito e se Desespera ao Saber que o Pai Vai Viajar" 2}

Música eletrônica ao fundo e holofotes apontando para o centro da tela, onde está escrito: "Ludimila". É como a abertura de um programa de televisão. Quando termina, já aparece a imagem de um carro. A câmera vai andando em sua direção. Então, é possível ouvir a voz de Ludimila dizendo: “Toda vez é isso." É ela quem filma.

O pai está com a mala na mão. Ele faz um carinho na cabeça do menino.

Pai: "Chora não, meu amor."

Mãe: "Seu pai não pode te levar na viagem."

Ela se dirige aos possíveis espectadores do vídeo.

Mãe: “Toda vez é isso, gente. É um escândalo.”

Depois, o pai pede para que tirem o menino do carro. O menino chora. É possível ouvir algumas risadas.

Mãe [para o pai]: "Como você se sente, amor?"

Pai: “Coração partido."

O vídeo segue com alguns acontecimentos entre a família. $\mathrm{O}$ avô do menino também aparece. Em 
seguida, o pai pede que segurem Lucas, entra no carro e inicia sua viagem. A mãe permanece filmando, deseja boa viagem ao marido e agradece a um pastor, que, pelo que se deduz, é quem está dirigindo. Há uma ruptura na captação do som. No retorno, é possível ouvir o menino chorando, desesperado, jogado no chão. Logo em seguida, ele se levanta e sai correndo atrás do carro pela estrada de terra. A mãe e o avô dão uma risada.

Avô: "Corre, vai."

Mãe: "Volta, Lucas. Vem, meu filho... Vem, bebê. Vem, Luquinhas."

O menino segue pela estrada. A mãe segue filmando até que o menino vai desaparecendo de vista.

Mãe: "Olha, gente, meu coração corta. Olha para isso."

De repente, um corte no vídeo. Ludimila aparece em cima de uma moto. Ela segue filmando pela estrada atrás do menino.

Mãe: "Volta aqui, Lucas!... Está chovendo, Lucas!... Você não pode ir atrás do seu pai. Para de bobeira, Lucas."

O menino continua correndo.

Mãe: “Lucas, eu não posso ficar atrás de você na chuva."

O menino olha para trás. A mãe diminui um pouco a velocidade da moto.

Mãe: “Coisa feia. Eu vou mandar esse vídeo para o seu pai.”

Ela vai se aproximando e, enfim, fica lado a lado com o filho. Depois de algumas aproximações e distanciamentos, a situação continua.

Mãe: “Vem, meu filho. Vem, Lucas, por favor. Tá chovendo. Meu celular está molhando.”

Lucas: "Deixa molhar. Eu quero meu pai."

Depois de muitas idas e vinda, o menino sobe na moto. Eles retornam para casa, mas o menino permanece chorando.

\section{Virais}

Antes mesmo que o leitor chegue ao final desta frase, um vídeo recém-postado na Internet já terá sido visualizado/acessado/compartilhado/replicado/mixado por milhões de pessoas, numa velocidade exponencial e sem precedentes. Como um vírus, transpondo mídias e plataformas, em questão de segundos, terá fundado uma esfera subjetiva comum em escala global.

O vídeo viral se caracteriza como uma produção audiovisual geralmente amadora, feita por uma pessoa de um círculo íntimo, na qual ocorre a situação filmada, registrada, na maioria das vezes, com um celular. Esse vídeo é publicado no ciberespaço, passando a compor o território de quem o postou, mas entrando no emaranhado que são as plataformas, os sites, as redes sociais. É uma produção audiovisual que ganha grande circulação no ciberespaço, gerando um impressionante número de visualizações. 
Há milhares de vídeos com crianças disponíveis no YouTube. O desejo de ver a infância em cena provoca sua viralização, desejo esse que pode se manter apenas à espreita, observador, sem interação ou intervenção, ou pode se apropriar das ferramentas do próprio YouTube e se expressar em comentários e avaliações. De uma forma ou de outra, esse desejo provoca a viralização. A infância, colocada no lugar do Outro, que pertence ao adulto, é, muitas vezes, tomada para o riso e para o entretenimento.

Dessa maneira, as infâncias que vão para as telas nos vídeos virais geralmente afirmam lugares idealizados: relações familiares, alimentação, contato com os animais, acidentes, "traquinagens", experiências com a cultura na música, na dança e com artefatos tecnológicos, desenvolvimento da linguagem, "não saberes" etc. Os adultos querem determinar o enquadramento dos momentos em que essas infâncias aparecem, mas, diante do jogo de forças, as crianças também podem tentar romper, negociando e resistindo. Assim, crianças circulam em produções audiovisuais e tornam-se virais, revelando as fisionomias das infâncias contemporâneas e, por alteridade, também as fisionomias dos adultos.

Tim e Lucas são apenas dois exemplos no grande emaranhado de vídeos virais dos quais as crianças são protagonistas. Essas e muitas outras situações dos cotidianos vividos pelas crianças estão disponíveis em produções audiovisuais a qualquer usuário do ciberespaço. Vídeos que apresentam crianças estão entre aqueles que mais viralizam.

O que torna a infância uma imagem tão visada e tão receptiva? Que aspectos da infância são apresentados ou destacados nesses vídeos? Em que medida essa circulação em larga escala contribui para a produção de um (des)lugar social para a infância na sociedade contemporânea? Como, nessa contagem em dígitos intermitentes e vertiginosos, pensar a ética do agir humano que se metamorfoseia em fenômeno viral?

\section{O Viral e o seu Antes}

Para enfrentar essas questões, mais do que focar na velocidade com que um vídeo é produzido e se replica, interessa-nos aqui desacelerar esse continuum da viralização e - com uma lentidão e um modo de espera também culturalmente aprendidos com as tecnologias das câmeras -, buscar e pausar o exato instante do "antes": antes do click; antes do rec; antes do upload; antes do compartilhar; antes do curtir. O antes do acontecimento. $\mathrm{O}$ antes da decisão. $\mathrm{O}$ antes. $\mathrm{O}$ exato instante em que o olho e a mão arquitetam o agir. Para isso, buscamos na arte cinematográfica - referência primeva de nossas experiências audiovisuais - elementos para uma reflexão que se faz urgente e necessária: o que queremos fazer existir com aquilo que filmamos e compartilhamos?

Antes da Chuva, filme de Milcho Manchevski (ANTES, 1994), convida a pensar nesse "antes", colocando em cena os conflitos étnico-religiosos da antiga Iugoslávia, em três partes que se reinventam, todas ambientadas num prenúncio de chuva. "Palavras" apresenta Samira, jovem albanesa em fuga, que corre desesperada e se refugia num mosteiro cristão, onde recebe a ajuda de um jovem religioso que fizera voto de silêncio. Em "Rostos", apresenta-se o personagem central da trama, Alexander Kirkov, fotógrafo de guerra em crise com sua profissão. Colega e amante de Anne, trabalham numa grande agência inglesa. "Fotografias" faz o elo entre as histórias: muitas das fotografias que Anne avalia são de guerra. São imagens de crianças com testas numeradas, pessoas assustadas, situações de pânico - muitas crianças, que há muito se configuram imagem receptiva ou impactante. Kirkov retorna à sua terra, a Macedônia, e encontra sua velha casa semidestruída e a família profundamente envolvida nos conflitos religiosos locais. Contrariando 
o esperado, os ciclos de guerra e paz que atravessam a história já haviam sido premonitoriamente grafitados num muro, como palavras de um oráculo: “O tempo nunca morre. O círculo não é redondo" - enigma que retorna, num enunciado já alterado, pronunciado por um dos padres do mosteiro: "O tempo nunca morre. O círculo nunca se fecha." O final do filme reposiciona totalmente o seu começo. E a chuva chega.

Antes da Chuva é emblemático para a crítica aqui proposta à viralização de vídeos. Primeiramente, por tratar-se de um dos filmes que inauguram, no cinema, uma reflexão sobre as guerras que passaram a ser transmitidas ao vivo, via satélite - a exemplo da Guerra do Golfo (1990-1991) - e a ser acompanhadas no cotidiano da sala de nossas casas, pela TV, como quem visualiza um jogo de videogame. A guerra tornara-se comunicação. Os avanços tecnológicos tornaram ordinário o que, até então, era extraordinário e as consequências éticas que se podem extrair dessa transformação subjetiva configuram o que está posto em questão no filme.

Em meio às muitas fotografias de guerra, que rendem a Kirkov um prêmio Pulitzer como reconhecimento de seu trabalho, o fotógrafo, já habituado a registrar a morte, é convocado a extrair as consequências éticas do seu agir. Ele tenta compartilhar com Anne essa reflexão num rápido encontro, em que se limita a dizer "Eu matei", frase que explicaria mais tarde, numa carta enviada:

Querida Anne,

O clima é agradável. Vai chover. Como está seu marido? Espero que esteja feliz com ele. Este lugar está igual a outros, mas meus olhos mudaram, como uma lente com um filtro novo.

Na semana passada, disse-lhe que havia matado. Tornei-me amigo de um militar e me lamentei, dizendo que não havia visto ação. Ele me disse: "Sem problemas!" Tirou um prisioneiro da fila e o matou ali mesmo. "Pegou esse?" - ele me perguntou. Eu peguei. Tomei partido. Minha câmera matou um homem. Não mostrei a ninguém essas fotografias. Agora são suas.

Com amor,

Alexander.

Kirkov sente-se responsável (e nós, que espectamos suas fotografias) pela morte desse homem. Em seu processo de reflexão, Kirkov produz dois tipos de deslocamentos: um, de caráter histórico, consiste em colocar em cena o "antes" da fotografia, o exato instante em que ela se coloca como necessidade humana a que ele responde tomando partido com o seu agir; outro, de caráter político-social, na medida em que reinstaura o fato comunicacional dando existência àquelas fotografias - ou seja, recolocando os sujeitos históricos diante do que desejam comunicar, questionando o próprio sentido da comunicação. Lembranos que, com nossa ânsia pelo extraordinário - mediada pela agência das fotografias que publica -, apertamos, junto com ele, o disparador-gatilho de sua máquina fotográfica.

Buscar o "antes" é aqui o balizamento de uma ética que se desenha a partir da recuperação da dimensão histórica da vida, da sua desnaturalização. Há que se buscar conhecer a história dos acontecimentos para podermos nos reconhecer como sujeitos da história e compreendermos como nos posicionamos nela. Nessa linha de pensamento, Mikhail Bakhtin $(2003$; 2015) apresenta o agir ético como forma de respondibilidade; ou seja, forma de, simultaneamente, responder a uma demanda social e responsabilizar-se pelo que se escolhe responder. Com isso, Bakhtin situa a ação humana no fluxo da história social. O agir expressa uma visão de mundo e uma tomada de partido por essa visão. 
Não há ingenuidade no agir, nem álibi. Entediar-se, como Kirkov, à espera de imagens espetaculares ou embevecer-se e compartilhá-las ilimitadamente são formas de agir no mundo - respondem a uma demanda e instauram desdobramentos a ela; posicionam-nos valorativamente na dinâmica social.

Filmar, postar, compartilhar, curtir, ver são atos valorativos. Buscamos refletir sobre a responsabilidade daqueles - geralmente adultos - que filmam e publicam vídeos com crianças. Não são quaisquer adultos. Pertencem ao círculo íntimo das crianças, geralmente são membros da família. Produzem, assim, extimidades, o que, como conceituou Sibilia, "consiste em expor a própria intimidade nas vitrines globais das telas interconectadas" (2016, p. 21). Embora não sejam imagens de si, os adultos expõem, nos vídeos, cenas só possíveis de ser capturadas na intimidade. São cenas absolutamente caseiras, que revelam situações das crianças em seus ambientes familiares.

Tim é um entre milhares de meninos que têm alguma atividade de sua relação familiar registrada em vídeo e publicada, principalmente, no YouTube. Na maior parte dessas produções, os adultos produzem a cena. Escolhem filmar e publicar a situação, em geral, porque há algum acontecimento que chame atenção ou tire a situação, aparentemente comum, da cotidianidade da vida. No caso de Tim, é uma cena que não parece acontecer pela primeira vez, mas que leva a mãe a aproveitar o momento para fazer o registro. Contudo, para que fazê-lo?

Ludimila, mãe de Lucas, explicita que filma toda a cena com o objetivo de compartilhar. Ela conversa com um possível espectador. Não para de filmar quando o menino se joga no chão; quando ele sai correndo pela estrada; quando ela vai atrás dele de moto; quando começa a chover. Mães, pais, irmãos, irmãs e avós aparecem em muitos vídeos virais apenas por meio da voz. Por vezes, são filmados em rápidas tomadas, em geral quando não são os produtores dos vídeos. As pessoas que filmam centralizam a filmagem quase integralmente na criança que protagoniza a situação e, enquanto filmam, buscam estimular as cenas que estão acontecendo. Elas interagem com as crianças sem deixar de lado o celular, artefato usado para fazer os vídeos. É como a conversa entre Kirkov e o soldado.

Embora tratando de emblemático momento histórico - em que os avanços tecnológicos permitiam superar o imaginário da guerra de trincheiras, transformando-a num jogo de videogame -, mais que da comunicação, o filme fala das impossibilidades dela, pois "a modernidade tecnológica produz em permanência comportamentos arcaicos preservados no interior da civilização que se pretende lógica e científica", como diz Olgária Matos (2015, p. 199) em texto dedicado ao filme. Segundo a autora, Antes da Chuva coloca em questão as regressões da sociedade diante de seu suposto avanço tecnológico: a fragmentação política, os fundamentalismos religiosos e os ódios étnicos. Qual é o sentido de uma civilização que se autoestima técnica e na qual "nada é sem razão" se ela se mostra ineficaz para zelar por sua própria manutenção? Qual é o sentido de tantos meios se o que os sujeitos comunicam é a violência?

Gilberto Gil, para falar do contexto atual da cibercultura, "atualizando" a clássica canção "Pela Internet", diz que "o movimento é drone" - veículo aéreo não tripulado, controlado remotamente. Essa foi uma tecnologia desenvolvida para a guerra, com objetivo de acertar alvos à distância e mais precisamente, mas que, hoje, tem sido usada por fotógrafos, cinegrafistas amadores ou órgãos de segurança pública, a fim de captar imagens de multidões presentes em shows ou manifestações. As imagens produzidas pelos drones seduzem, mas eles também são capazes de espionar, seguir e perseguir. Em guerra, tanto capturam a imagem quanto disparam contra o alvo encontrado. À distância, garantem imagens e/ou "morte asséptica", como num videogame.

No caso dos vídeos virais, há uma distância técnica, que faz da imagem cotidiana (talvez comum a todos nós) uma imagem asséptica, na qual não nos reconhecemos ou com a qual não construímos empatia. Se Lucas está sofrendo ou se Tim irá derrubar os equipamentos da mãe, o importante é fazer o vídeo. A chuva 
que molha o celular parece não molhar o menino. Interessa produzir o vídeo. Ao ser replicado, é como se a criança tivesse que viver infinitamente a mesma cena. Uma prática sensacionalista, por vezes abarrotada de requintes de crueldade, como as risadas dadas diante do sofrimento da criança. Os produtores dos vídeos (e aqueles que o viralizam), mesmo vendo e/ou vivendo uma situação extrema, não indagam sobre a responsabilidade do seu agir.

\section{Princípios para o Agir}

Em seu clássico texto "A obra de arte na era de sua reprodutibilidade técnica", datado de 1936, Walter Benjamin (1987) sinaliza que, para tomarmos consciência das técnicas e das tecnologias de cada época, devemos estudar profundamente aquelas que as antecedem. Isso porque, das técnicas e tecnologias de que somos contemporâneos, temos uma visão parcial, tergiversada por nossa própria existência. Antes da Chuva coloca em questão um momento histórico que antecipa o drone e inaugura um novo parâmetro tecnológico de guerra - territórios escaneados em luz infravermelha; aviões não tripulados; mísseis disparados à distância por computadores; "bombas inteligentes" etc. Todavia, em tempos de memória fixada em nuvem, o velho ato fotográfico permite ainda formular indagações sobre as imagens que tornamos sem corpo, sem cheiro, sem apelos de alteridade.

Nesse contexto, a cibercultura constitui, por um lado, possibilidade de ampliação do mundo social e cultural - como acessar as galerias de um museu sem sair de casa; por outro, eterna continuidade e sobrecarga de trabalho que nos exaure. O ciberespaço é, para cada pessoa que o acessa, um território delimitado pelas escolhas que faz. É um mosaico de textos, imagens e sons. Dessa maneira, constituímos nossa existência a partir da existência virtual do Outro. Talvez por isso mesmo produzamos nossa "extimidade", disponibilizando em rede acontecimentos comuns no dia a dia e nos quais, por vezes, ocorre algo atípico - tudo isso mediado pelas inúmeras máquinas de ver e, especialmente, pelas telas. A tela torna-se o artefato do contato, das conexões, das narrativas. É o artefato que nos acompanha sem nos fazer perder o apetite. Nisso, vamos constituindo a mitologia do nosso tempo, impreterivelmente, com as crianças e a exposição de suas infâncias.

Diferentemente da história narrada, em que Alexander Kirkov precisa capturar o extraordinário num contexto de exceção - a guerra -, a produção e a circulação de vídeos virais afetam sujeitos ordinários (CERTEAU, 2008) no afã de registrar seu cotidiano também ordinário com as máquinas de seu tempo. Acordar, dormir, comer: gestos aparentemente banais do dia a dia que ganham notoriedade ao ser filmados e compartilhados. O que torna "filmáveis" os quiproquós do cotidiano? O que torna compartilháveis esses filmes? O que os torna virais? Nessas questões, reside a sutileza que transforma o ordinário em extraordinário. O que queremos mostrar? A análise dessas produções audiovisuais nos dá indícios de alguns formatos sugestivamente viralizáveis. Majoritariamente, os vídeos são postados e compartilhados por provocarem o riso, ainda que as situações filmadas não sejam cômicas para as crianças que nelas estão.

Enquanto crianças aparecem sofrendo, pedindo ajuda ou em situação de risco, adultos permanecem filmando, intencionalmente, a fim de publicar o vídeo. São situações nas quais crianças estão angustiadas, mas ainda assim são filmadas. Nos diálogos provocados pelos adultos que filmam, tais crianças são estimuladas a continuar a situação que as incomoda ou que as coloca em algum risco. Não há, por parte de quem filma, uma intervenção externa de acolhimento ou de ajuda para solucionar o problema que a criança enfrenta. Ainda que a criança o solicite. Os adultos seguem segurando o celular para registrar a criança. É possível perceber o riso de alguns deles. Algumas filmagens chegam a tremer por causa do riso das pessoas que filmam. Enquanto isso, as crianças estão na mira do celular. Em algumas situações, até aparecem falas de consolo ou de conforto para as crianças, mas a filmagem continua deixando evidente que é mais importante filmar que as acolher. 
Ao filmar e publicar, naturaliza-se o sofrimento da criança diante da câmera, pois pouco importa o fato de a cena ficar exposta na vitrine global que se tornou o YouTube. Não causa espanto, revolta ou comoção a situação vivida pela criança. Parece haver uma aura que coloca, por exemplo, o choro da criança - ser tido como inocente, fofo, ingênuo - como algo natural, quase bonito de ser visto (como se não expressasse sofrimento suficientemente forte para ser encarado com cuidado e respeito). Equivale a afirmarmos que "tudo bem" a criança chorar. Mais que isso: o choro, que representa aquela ideia romântica de infância, precisa ser visto por todos. $\mathrm{Ou}$, ainda, é o choro que atrai o público, devendo ser filmado e compartilhado. Não à toa, em muitos vídeos, os adultos aparecem também dialogando com o possível espectador de sua produção. É um desejo de olhar cenas das infâncias e transformar esse olhar em vídeos para que outros também possam vê-lo. Talvez, como nos mostram alguns comentários em vídeos, provoquem espanto, revolta ou comoção em quem os assiste, mas é uma plateia que permanece confortável atrás das telas.

Não há filtro na exposição dessas produções. Os vídeos ficam disponíveis no YouTube; podem ser vistos por qualquer usuário da plataforma. Para além disso, quando publicados, podem ganhar dimensão de uso incontrolável pelos demais usuários do site. Essas produções são baixadas e republicadas em outros canais do próprio YouTube; e podem passar a circular em outras redes sociais, como Facebook e Instagram, ou por meio de aplicativos de mensagens, como o WhatsApp.

Dentro da cibercultura, marcada pela cultura da participação na cultura da convergência (JENKINS, 2009), por uma ideia remix (LEMOS, 2005), os vídeos são editados. Tornam-se outras produções, como canções ou memes. As imagens das crianças são apropriadas por qualquer usuário e circulam ressignificadas no ciberespaço. Não há controle sobre os usos que ganham.

\section{Considerações Finais}

Por um lado, as redes sociais on-line permitiram uma experiência de comunicação sem precedentes, na medida em que todos com acesso aos aparatos técnicos podem compartilhar a autoria da comunicação ali produzida; por outro, essa multidão em rede pode não ter por princípio comum a comunicação - ou seja, embora tecnicamente conectada, talvez não forme uma comunidade no sentido político. Embora amalgamadas entre si, há que se considerar as nuances que transcendem a realidade social supostamente visibilizada nas redes on-line.

Aqui se evidencia a necessidade de erigir uma ética para a produção e a circulação de audiovisuais nas redes sociais. Queremos destacar aqui o lugar social e político das crianças no contexto da cibercultura sobretudo na produção e na circulação de vídeos virais. Apesar da dificuldade de atribuição de autoria a essas produções, é possível, a partir da pesquisa empírica que embasa esta reflexão (SILVA, 2015, 2019), afirmar que as crianças aparecem, majoritariamente, como imagem-objeto desses vídeos e, em escala bastante reduzida, como seus autores. A infância é objeto de fetiche em produções audiovisuais e tem sua plateia cativa. Não é de hoje que representa uma imagem idílica, usada no campo da publicidade para vender. É explícita a vontade de expor essas cenas da vida infantil, assim como se sabe que há um público que anseia por essas produções. A ideia idílica de infância não se incomoda em aviltá-la, desde que sacie o voraz desejo contemporâneo por vídeos.

Há um mercado na viralização. Olgária Matos (2015) chama-nos a atenção para a permanência de comportamentos arcaicos a despeito de nossa sociedade se autoproclamar extremamente tecnológica. É preciso considerar o arrefecimento dos laços pessoais, a exemplo de afeto, solidariedade e empatia, que, sob o ideário capitalista transformaram-se em relações de poder regidas pela competição e pela aceleração da produtividade. 
O esgarçamento da comunidade política, um dos traços mais essenciais da tradição democrática, faz com que se perca a confiança nos concidadãos e a radicalidade dessa insegurança vai se instalar nas posturas sectárias ou fundamentalistas de determinados grupos - ou mesmo no espaço privado da família, no qual as relações dogmáticas substituem o afeto (MATOS, 2015). Isso pode ser observado mais explicitamente, no filme de Milcho Manchevski, a partir dos conflitos político-religiosos que estruturam a vida e a morte em seu roteiro; mas também pode ser percebido nos vídeos virais que apresentam crianças, produzidos e estimulados por seus familiares, muitas vezes desconsiderando os apelos infantis ou os perigos que se mostram iminentes.

Tim e Lucas conferem fisionomias à infância contemporânea, viralizada em vídeos nas redes sociais on-line. É a violência que cerceia Lucas o que nos mostra que não há inocência na câmera que enquadra Tim. Cada vídeo mostra que a suposta imagem idílica da infância pode revestir uma imagem de violência. Não há ingenuidade na sociedade da técnica. Aqui se desnudam as metáforas do não fechar do círculo e da imortalidade do tempo, para afirmar que, assim como o futuro, também o passado é contingente e carece de reformulações. Deve-se refazer quantas vezes for necessário o tal círculo que não se fecha, buscando no tempo que não morre a inevitável pergunta sobre o "para que" filmamos e viralizamos a infância. Mirar o "antes", quando se gesta o agir e a tomada de partido.

Nesse limiar entre o que parece ordinário, mas que traz algo de extraordinário, cabe-nos sempre indagar antes de cada click, de cada start na câmera do celular: "Que lugar reservamos às crianças?"; "Para que as registramos?”; "Para que as expomos?”; "O que dizemos de nós nesse minúsculo agir?”

\section{Contribuições dos Autores}

Conceptualização: Silva P, Pereira RMR; Metodologia: Silva P, Pereira RMR; Redação: Silva P, Pereira RMR.

\section{Notas}

1. O vídeo tem 2 minutos e 27 segundos. Quando trazido para pesquisa, em novembro de 2018, tinha 2.356 .503 de visualizações. Estava disponível em: https://www.youtube.com/watch?v=EZBp3ovOe8w. No entanto, foi retirado do ar durante o processo de editoração deste texto.

2. O vídeo tem 5 minutos e 3 segundos, com 17.412.002 de visualizações. Disponível em: https://www.youtube.com/ watch?v=NS9jCAiFloM. Acesso em: 29 fev. 2019.

\section{REFERÊNCIAS}

ANTES da Chuva. Direção: Milcho Manchevski. Reino Unido/França/Macedônia: Aim/British Screen Productions/European Co-production Fund/Ministry of Culture for the Republic of Macedonia/Noe/ PolyGram Audiovisuel/Vardar Film, 1994.

BAKHTIN, M. Estética da criação verbal. São Paulo: Martins Fontes, 2003. 
BAKHTIN, M. Por uma filosofia do ato. São Carlos: Pedro e João Editora. 2015.

BENJAMIN, W. "A obra de arte na era de sua reprodutibilidade técnica”. In: Obras Escolhidas. São Paulo: Brasiliense, 1987, v. 1.

CERTEAU, M. A invenção do cotidiano. Petrópolis: Vozes, 2008. (1. Artes de fazer.)

JENKINS, H. Cultura da convergência. 2. ed. São Paulo: Aleph, 2009.

LEMOS, A. Ciber-Cultura-Remix. Artigo apresentado no seminário SENTIDOS E PROCESSOS, no Centro Itaú Cultural, São Paulo, ago. 2005. Disponível em: https:/www.facom.ufba.br/ciberpesquisa/andrelemos/ remix.pdf. Acesso em: 10 ago. 2019.

MATOS, O. C. F. Antes da chuva: Metamorfoses do círculo. Psicologia, São Paulo, v. 26, n. 2, p. 199-207, 2015. https:// doi.org/10.1590/0103-6564A20150001

SIBILIA, P. O show do eu: A intimidade como espetáculo. Rio de Janeiro: Contraponto, 2016.

SILVA, P. Narrativas multimídias de infâncias contemporâneas: Crianças no YouTube. In: PEREIRA, R. R. et al. Infância, juventude e educação: Práticas e pesquisas em diálogo. Rio de Janeiro: NAU, 2015, p. 191-209.

SILVA, P. Fisionomias das infâncias contemporâneas na cibercultura: Crianças em vídeos virais. 2019. 177 f. Dissertação (Mestrado em Educação) - Faculdade de Educação. Universidade do Estado do Rio de Janeiro, Rio de Janeiro, 2019.

Recebido: 06 Jan. 2020

Aceito: 10 Jul. 2020

Editoras Associadas:

Adriana Laplane e Lucia Reily 